Egypt. Acad. J. Biolog. Sci., 10(1): 63 - 77 (2018)

Egyptian Academic Journal of Biological Sciences

D. Histology \& Histochemistry

ISSN: $2090-0775$

www.eajbs.eg.net

\title{
Histological, Histochemical and Ultrastructure Studies on the Ostrich Pancreas
} (Struthio camelus)

Seham A. Helmy ${ }^{1,2}$, Mohammed T. A. Soliman ${ }^{3}$

1-Department of Cytology and Histology, Faculty of Veterinary Medicine, Suez

Canal University, Ismailia, Egypt

2-Department of Nursing, College of Applied Medical Sciences, University of Bisha,

Bisha 61922, p.o. Box 551, Saudi Arabia.

3-Department of Medical Laboratory Sciences, College of Applied Medical Sciences, University of Bisha, Bisha 61922, p.o. Box 551, Saudi Arabia

\section{ARTICLE INFO}

Article History

Received:6/10/2018

Accepted: 25/11//2018

\section{Keywords:}

(ostrich, pancreas,

histology,

histochemistry,

Ultrastructure).

\section{INTRODUCTION}

Ostriches (Struthio camelus) are the most important species of ratites group, in which the great potential value of ostrich for the lean production of high nutritious quality, and of little cholesterol content (Christaki 2001; Brand et al. 2003). Furthermore, ostrich is used for the production of leather, feathers, eggs and oil 
production`(Seham 2004; Saber et al. 2009). The body fat level of the ostrich is the lowest of all avian commercial species. In contrast to chickens, the low body fat is maintained in ostrich, in spite of artificial selection for growth, due to the high concentration of protein in their diet, Hermes (1996) and Seham (2004).

The pancreas of the birds located on the right aspect of the abdomen and it is represented as an important mixed large gland related to the gastrointestinal tract (Deprem et al. 2015; Beheiry et al. 2018).The pancreas is bi-function gland, having the properties of endocrine and exocrine glands. The exocrine portion forms the majority of the pancreas, the acinar cells and its associated excretory ducts (Pieler \& Chen 2006). This portion secrets the pancreatic amylase, lipase and proteinases which aid in the chemical digestion of the food (Frandson et al. 2009; Denbow 2015). The endocrine portion produces hormones such as insulin, glucagon and somatostatin, which control the level of blood glucose ( $\mathrm{Ku}$ et al. 2000; Mescher 2010; Deprem et al. 2015).

The macroscopic, microscopic and ultrastructure of the pancreatic lobes have the attention of many researchers. Existence of various hormone producing cells was demonstrated in the pancreas of avian species including duck (Lucini et al. 1996; Das et al. 2003) chicken (Kalliecharan \& Steeves 1982; Cooper et al. 1997), goose (Nagasao et al. 2003) and pigeon (Mihail \& Crăcium 1982; Mobini 2013). In spite of this, papers that had discussed the fine histological structure of the pancreas in ostrich were rare (Stornelli et al. 2006; Bacha et al. 2007). Therefore the present investigation, designed to explore the histological, histochemical and the electron microscopic features of the ostrich's pancreas with special reference to the cellular contents of both exocrine and endocrine parts.

\section{MATERIALS AND METHODS}

Eight adult apparent healthy male ostriches were used. They collected from private ostrich farms in Assuit government, Egypt.

\section{Histological Studies:}

Specimens from the different lobes of the pancreas were collected and examined grossly to be free of any apparent abnormalities. The specimens were immediately immersed in $10 \%$ neutral buffered formalin and Bouin's solution for paraffin embedding. Sections (4-5 $\mu \mathrm{m})$ thickness were obtained and processed for Hematoxyline \& Eosin (H\&E) for general characters (Cook \& Stirling 1994). Modified Gomori's aldehydefuchsin stain for beta cells and pancreatic islet cells. This stain shows beta ( $\beta$-cells) in deep purple-violet, alpha ( $\alpha$-cells) in yellow color and delta $(\Delta$-cells) in green color Carleton et al. (1980).

\section{Enzyme Histochemistry:}

Specimens were rapidly taken and immersed in liquid nitrogen $\left(-196{ }^{\prime} \mathrm{C}\right)$, put in a cryostat at $\left(-20^{\prime} \mathrm{C}\right)$ and cut into a section of 10 um thick, then subjected to different reactions for detection of enzymes: Calcium cobalt method for detection of alkaline phosphatase. Gomori's lead method for demonstration of acid phosphates. Nitro-blue tetrazolium (NBT) method for detection of Succinic dehydrogenase (SD). Modified myosin ATPase technique for demonstration of Adenosine-triphosphatase (ATPase) Cook and Stirling (1994) was performed.

\section{Transmission Electron Microscopy (TEM):}

For TEM a small section of $1 \mathrm{~mm}^{3}$ was immersed in 5\% glutaraldehyde in IM phosphate buffer ( $\mathrm{pH}$. 7.3) for 24 hours then post fixed in cold IM phosphate buffered $1 \%$ osmium 
tetroxide (pH. 7.3) for 3 hours, washed in phosphate-buffer for half an hour then dehydrated. Semi-thin sections were stain by toluidine blue (T.B.). Ultra-thin sections were gained and mounted on copper grids then stained with uranyl acetate and lead citrate according to the protocol of E.M. unit Assiut University. Bozzol and Russell (1999).

\section{RESULTS}

The ostrich pancreas was surrounded with a thick connective tissue capsule which composed of collagen, reticular and elastic fibers. This capsule gave septa to the parenchyma which divided it into numerous pancreatic lobules. The parenchyma consisted of exocrine and endocrine parts that were supported by a thin reticular stroma. The exocrine portion was in the form of acini, where digestive enzymes were secreted. The endocrine portion was found as a group of cells forming islets as well as singly scattered in-between the acini.

\section{The Exocrine Portion:}

Many sections prepared from different portions of the pancreas showed the exocrine part was formed of serous acini. The acinar cell was large pyramidal with large rounded vesicular nucleus located basally with prominent nucleoli. The cytoplasm of the cells contained fine deeply acidophilic zymogenic granules mainly located in the apical portion facing the lumen of the acinus. The acinar lumen appeared very narrow and most difficult to be distinguished. The pancreatic ducts in the lobule were small and lined by simple cuboidal epithelium and its lumen contained secretory material (Fig. 1a\&b).

Ultrastructurally, the acinar cells forming the pancreatic acini appeared pyramidal having a basally large vesicular nucleus with prominent large nucleoli which appeared spherical and electron dens. The cells were very rich with a rough endoplasmic reticulum (rER) especially in the bottom of the cells and around the nucleus. The other cell organelles such as mitochondria, Golgi apparatus, free ribosomes, and lysosomes are present. The secretory zymogenic granules appeared in form of homogenous electron dens spherical material variable in size up to $1000 \mathrm{~nm}$ and scattered throughout the apical parts of the cells. The acinar lumen sometimes contained secretory material and the luminal surface having microvilli. The junction complex between the acinar cells appeared in form of electron dens line in the upper portion of the cell membrane (Fig. 1c\&d).

\section{The Endocrine Portion:}

Islets of cells (Fig. 1a) formed the endocrine part. These islets were variable in shape, size and composed of abundant cells varies in shape, size and distribution. According to the population of the different type of the cells in the islets, the islets could be classified into beta islets (Fig. 1e), alpha islets (Fig. 1f) and mixed islets.

According to the staining affinity with (T.B.) stain, faintly stained beta cells and numerous moderately stained alpha cells (Fig. 2a) mostly formed the beta islets. Moderately stained alpha cells and the other faintly stained beta cells (Fig. 2b) mostly formed the alpha islets. These cells were rounded, oval, columnar or polygonal in shape having vesicular nucleus. Moreover, the islets showed the presence of numerous blood vessels in between the cells.

The beta islets, which appeared lightly, stained with (T.B.) stain contained a large number of beta cells and a small number from alpha and delta cells around it. The beta cells within the islets were differed in its distribution, some of them existed in the center of the islets, others islets contained randomly distributed beta cells some in the center other in the margin of the islets (Fig. 1e\&2c). The alpha islets which appeared moderately stained with (T.B.) stain may contain only 
alpha cells or a large number of alpha cells with few numbers of beta cells (in the center of the islets) and delta cells (Fig. $1 \mathrm{f} \& 2 \mathrm{~d})$.

The mixed islets that consisted of nearly equal number of alpha and beta cells with little delta cells were also observed. The alpha and beta cells with their characteristic fine structure were found singly between the acinar cells (Fig. $2 \mathrm{e})$.

Ultrastructurally, the endocrine cells according to the morphological structure were three types, beta, alpha and delta cells. Beta cells were large ovoid or polygonal with large nuclei. These cells contained variable sized and shaped secretory granules. Such granules were electron dens and ranging about $180-300 \mathrm{~nm}$ in size with the presence of halo zoon between its limited membrane and the content. Beta cell which contained abundant secretory granules had few cell organelles such as mitochondria, endoplasmic reticulum and free ribosomes while those contain little secretory granules having abundant cell organelles (Fig. 2f).

Alpha cells were elongated or polygonal and contained a large vesicular nucleus. Its cytoplasm contained electron dense secretory granules. The secretory granules spherical or oval with indistinct space between the limited membrane and the content with ranging size about 450$550 \mathrm{~nm}$. Also the cells contained little amount of organelles such as mitochondria, endoplasmic reticulum and free ribosomes (Fig. 3a).

Delta cells appeared oval or triangular having a vesicular nucleus with electron dense chromatin. The cell organelles such as mitochondria, endoplasmic reticulum and free ribosomes were also present. Delta cells contained spherical electron dense granules 300$450 \mathrm{~nm}$ in size. The limited membrane of the secretory granules was closely adherent to its content. In addition, the electron density of the granules was variable where some of them appeared light in electron density or immature and others were high in electron density (Fig. $3 b)$.

Histochemically, the pancreatic islets as well as alpha and beta cells, which found sporadically in between the acini, showed a strong to moderate reaction for acid phosphatase and intense to strong reaction to ATPase. The acinar cells showed relatively faint reaction to acid phosphatase and weak reaction ATPase (Fig. 3c\&d). Furthermore the islets and the acinar cells showed a strong reaction to alkaline phosphatese and succinic dehydrogenase meanwhile, blood vessels show an intense reaction to alkaline phosphatase (Fig. 3e\&f). 

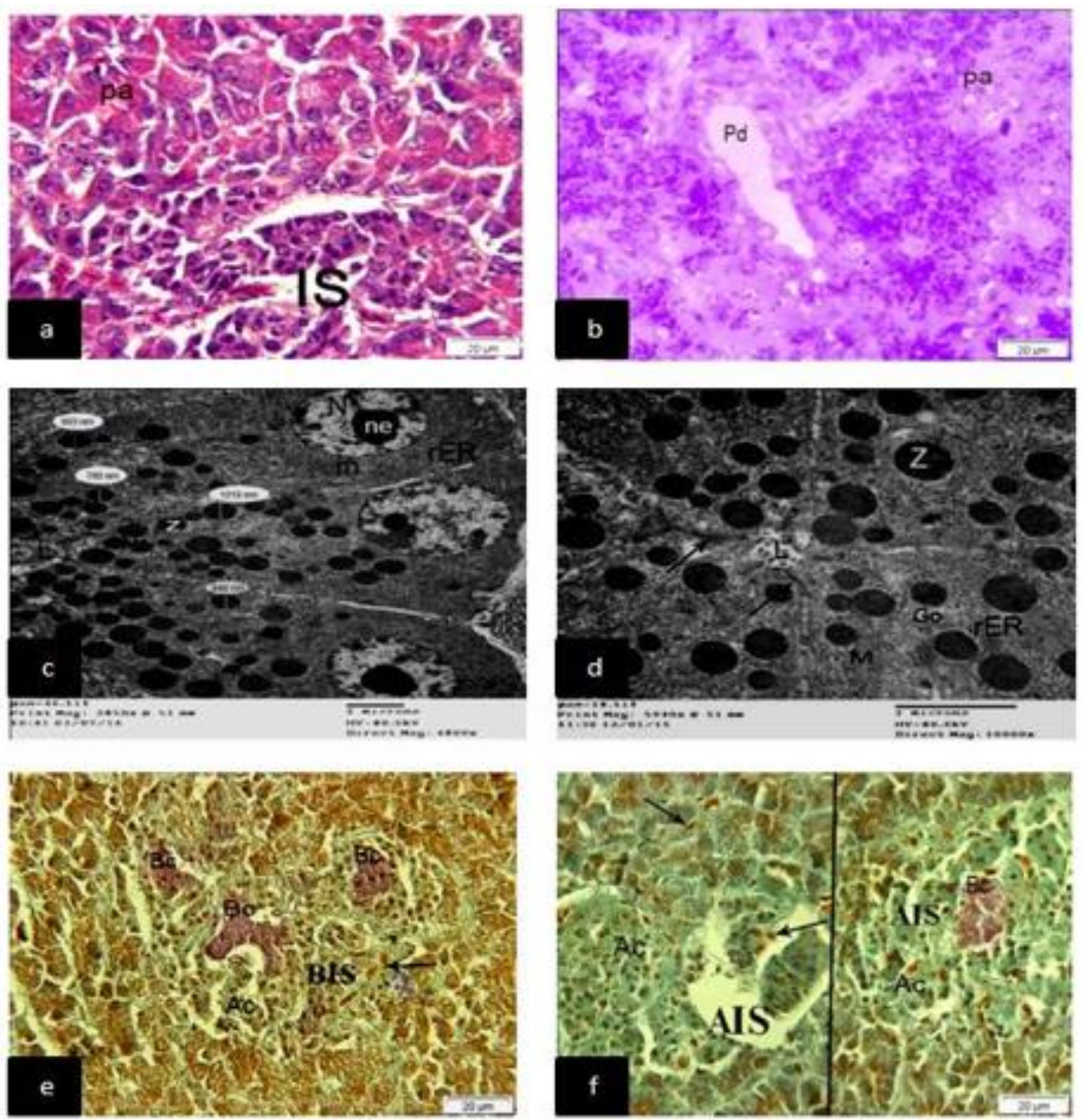

Fig. 1:

(a): photomicrograph of the pancreas is showing the pancreatic acini (Pa) contain zymogenic granules, islets of Langerhanse (IS). Hematoxyline \& Eosin (H\&E) stain, scale bare $(20 \mu \mathrm{m})$. (b): photomicrograph of the pancreas is showing the acini of the exocrine portion formed by large cells $(\mathrm{Pa})$ contained a vesicular nucleus and a fine deeply stained granules. Noticed presence of pancreatic ducts (pd) lined by low cuboidal cells. Toluidine blue (T.B.) stain, scale bare $(20 \mu \mathrm{m})$.

(c): transmission electron (T.E.) micrograph of pancreatic acini is showing: the pyramidal shape of the acinar cells contain a large vesicular nucleus $(\mathrm{N})$ with nucleolus (ne), rough endoplasmic reticulum (rER), mitochondria (m), zymogen granules (z). presence of pancreatic secretion in the acinar lumen (L) is noticed.

(d): T.E. micrograph of the pancreatic acini is showing: the acinar lumen (L), the presence of microvilli in the luminal surface of the cells, and dismosome (arrow). There are zymogenes granules (z), RER, Golgi apparatus (Go) and mitochondria (M) were noticed in the acinar cells.

(e): photomicrograph of the pancreas is showing: beta islet (BIS) contain, B cells (Bc) which vary in its distribution some in the center of the islet other in the periphery, alpha cells (Ac) and blood vasculatures in between (black arrow). (Modified Aldehyde-Fuchsin stain), scale bare $(20 \mu \mathrm{m})$.

(f): photomicrograph of the pancreas is showing: alpha islet (AIS) contains alpha cells (Ac), some beta cells $(\mathrm{Bc})$ in the center and blood vasculatures in between (black arrow). (Modified Aldehyde-Fuchsin stain), scale bare $(20 \mu \mathrm{m})$. 

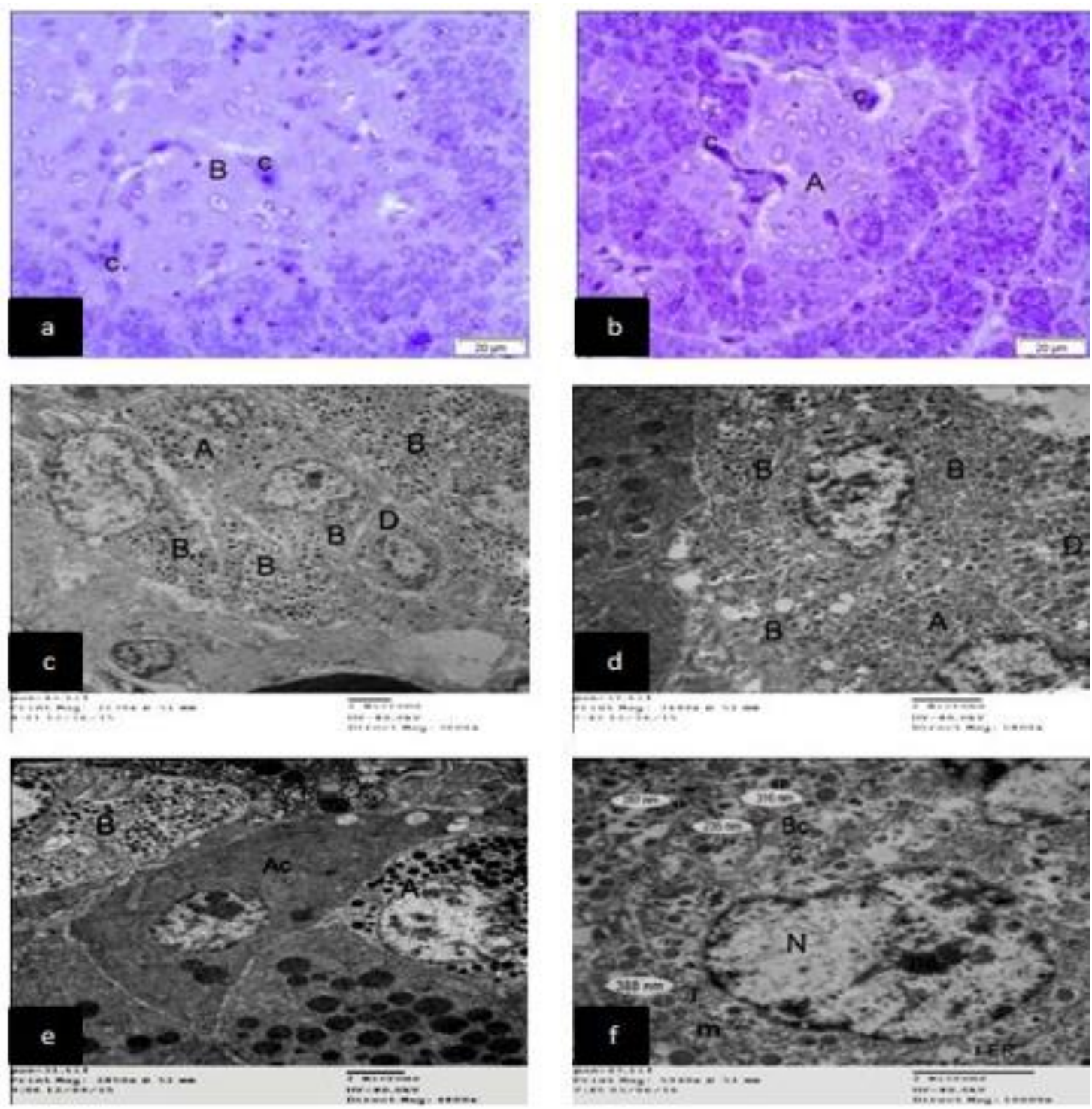

\section{Fig. 2:}

(a): photomicrograph of the pancreas is showing: beta islets of Langerhans (B) where the most cellular component faintly stained and surrounded by acinar cells. Presence of blood vasculatures (c) is noticed. (T.B. stain), scale bare $(20 \mu \mathrm{m})$.

(b): photomicrograph of the pancreas is showing: alpha islets of Langerhans (A) where the most cellular component moderately stained and surrounded by pancreatic acinar cells. The presence of blood vasculatures (c) is noticed. (T.B. stain), scale bare $(20 \mu \mathrm{m})$.

(c): T.E. micrograph of the pancreas is showing: beta islets formed by many beta cells (B), little alpha cells (A) and delta cells (D).

(d): T.E. micrograph of the pancreas is showing: alpha islets formed by numerous alpha cells (A), little beta cells (B) and delta cells (D).

(e): T.E. micrograph of the pancreas is showing: alpha cell (A) and beta cell (B) found singly in between the acinar cells (Ac).

(f): T.E. micrograph of beta cell $(\mathrm{Bc})$ is showing: a large vesicular nucleus $(\mathrm{N})$ with nucleolus (ne), secretory granules $(G)$ variable in size and shape surrounded by hallo zone, rER, mitochondria $(\mathrm{m})$ and free ribosome $(\mathrm{r})$. 

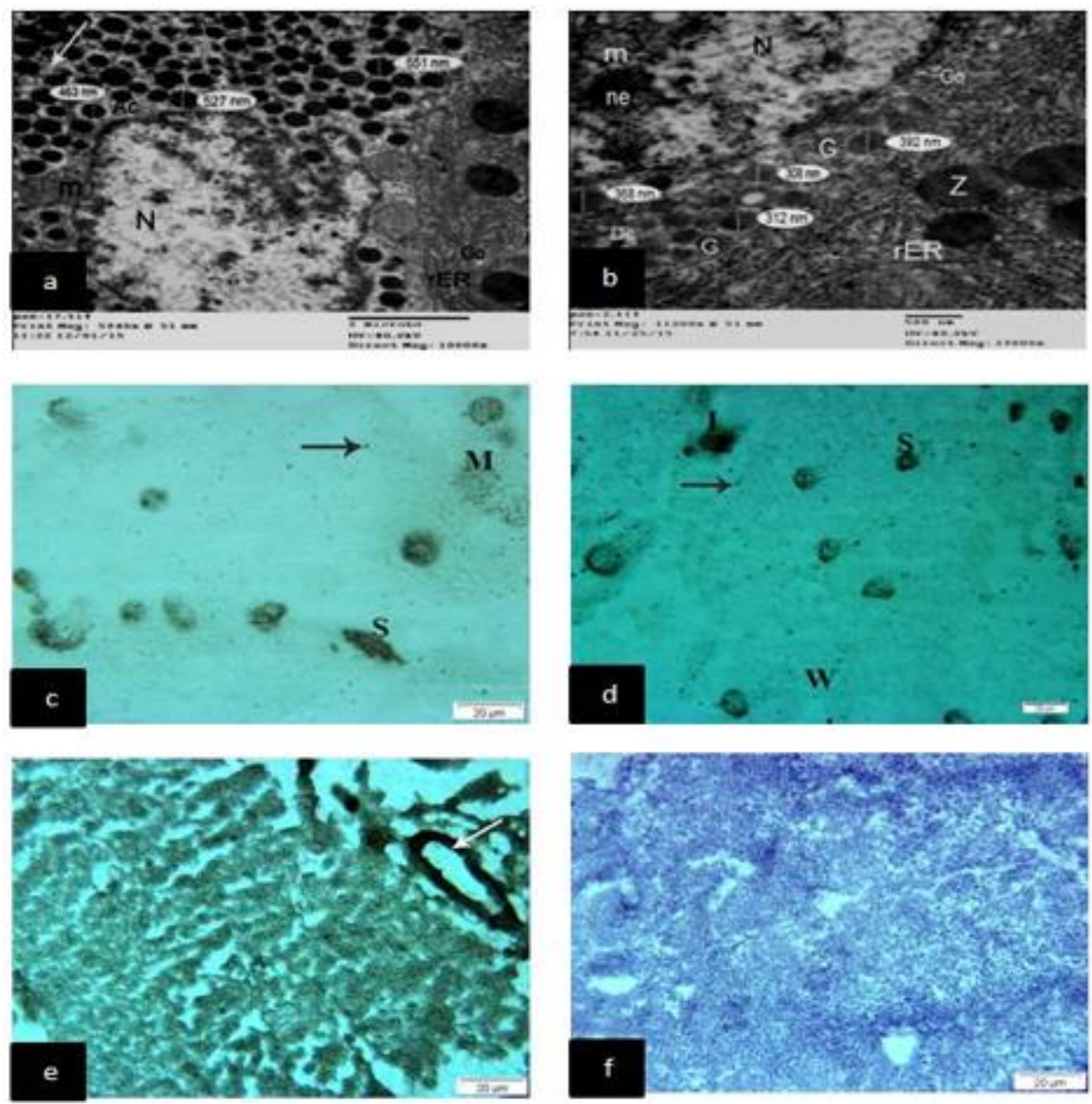

Fig. 3:

(a): T.E. micrograph of the alpha cell (Ac) is showing: large vesicular nucleus $(\mathrm{N})$, variable size secretory granules $(\mathrm{G})$, mitochondria $(\mathrm{m})$, rER and free ribosome (arrow). Notice the presence of acinar cell contain zymogen granules (z), rER and Golgi apparatus (Go).

(b): T.E. micrograph of delta cell (Dc) showing: large oval nucleus (N) with nucleolus (ne), secretory granules $(\mathrm{G})$ variable in size and electron density, mitochondria $(\mathrm{m})$ and Golgi apparatus (Go). Notice the acinar cell with zymogen granules (z) and rER.

(c): photomicrograph of the pancreas is showing, strong (S) to moderate (M) reaction to acid phosphatase in the islets as well as alpha and beta cells (arrow) which found sporadically between the acinar cells while the acinar cells showed a relatively faint reaction. (Gomori's lead stain), scale bare $(20 \mu \mathrm{m})$.

(d): photomicrograph of the pancreas is showing, intense (I) to strong (S) reaction to ATPase in the islets as well as alpha and beta cells (arrow) which found singly between the acinar cells but the acinar cells showed a relatively weak reaction. (Modified myosin ATPase stain), scale bare $(20 \mu \mathrm{m})$.

(e): photomicrograph of the pancreas is showing, a strong reaction to alkaline phosphatase in the islets and the acinar cells meanwhile the blood vessels is showing intense reaction (arrow). (Calcium cobalt stain), scale bare $(20 \mu \mathrm{m})$.

(f): photomicrograph of the pancreas is showing, a strong reaction to succinic dehydrogenase in the islets and the acinar cells. (Nitro-blue tetrazolium (NBT) stain), scale bare $(20 \mu \mathrm{m})$. 


\section{DISCUSSION}

The ostrich pancreas was surrounded by a thick capsule of connective tissue mainly composed of collagen and reticular fibers. This capsule was covered by flat mesothelial cells. This finding was in agreement with Gatesy (1995) in all mammalian and poultry species. Also, Mobini and Aghaabedi (2009) supposed the same structure in turkey. In contrast, the capsule of the pancreas was thin in geese (Kadhim et al. 2010; Al-Sharoot 2016), in pigeons (Mobini 2013), in duck (Das et al. 2003) and in red jungle fowl (Kadhim et al. 2010).

The parenchyma of ostrich pancreas consisted of exocrine and endocrine portions which contained thin reticular stroma. This fact concord with Aughey and Frye (2001), stornelli et al., (2006), Ghosh (2007), Kadhim et al., (2010), Saadatfar et al., (2014), Faris (2012), Mobini (2013) and Hamodi et al., (2013) in most birds.

The exocrine part formed by large pyramidal secretory acini which contained fine deeply stained zymogenic granules mainly located in the apical portion facing the lumen of the acini, but Das et al., (2003) in duck, Mobini and Aghaabedi (2009) in turkey and Mobini (2013) in pigeon, reported that, the shape of secretory acini varied from tall columnar to polygonal cells, also it is columnar in goose Gulmez (2003).

The duct system in ostrich pancreas composed of centro-acinar duct, intercalated ducts, intralobular ducts, interlobular ducts and the main excretory ducts (Das et al. 2003; Gulmez 2003). In our study the pancreatic ducts in the lobule appeared as small duct and lined by simple cuboidal epithelium and its lumen contained secretory material. This finding concord with Stornelli et al., (2006) in ostrich and Nagasao et al., (2003) in chicken. On contrast Mutoh et al., (1999) in fowl pancreatic intercalated duct gave a changeable description of the duct as it lined by quite inconspicuous cells that seemed to appear as stellate cells. Mobini (2013) in pigeon mentioned that, the epithelium of the duct system varied from simple squamous epithelium in the intercalated duct, to tall columnar epithelium in the main excretory duct.

The acinar cells appeared pyramidal having basally large vesicular nucleus with prominent large nucleoli which appeared spherical and electron dense, in contrast Simsek and Al-abay (2008) in quail and Beheiry et al., (2018) in goose distinguished the ultrastructure of some acini as an electron dense and the other as electron lucent in which the electron dense acinar cells contained electron dense cytoplasm and heterochromatic nuclei. The electron lucent acinar cells were less in number but active with euchromatic nuclei and prominent nucleoli.

The acinar cells very rich with (rER) specially in the bottom of the cells and around the nucleus, these finding are in agreement with Stornelli et al., (2006) in Ostrich, Beheiry et al., (2018) in goose who establish that the abundant (rER) and Golgi complex were capable of secret a permanent amount of mucopolysaccharides forming a glycocalyx that supports the mucosal surface from the effect of pancreatic secretion.

The other cell organelles such as mitochondria, Golgi apparatus, free ribosomes, and lysosomes are founded. These results are in agreement with Egerbacher and Bock (1997) who found many pleomorphic and enlarged mitochondria. The acinar cells contained proteases which are present as inactive zymogenic granules, in which this granules appeared in form of homogenous electron dense spherical material variable in size and scattered throughout the apical parts of the cells, 
these findings are in agreement with Take et al., (2007) and Beheiry et al., (2018) in goose. Mescher (2010) confirmed that, every cell contained zymogenic granules which vary in its number as it decreased in samples collected after the meal.

The endocrine part of the pancreas is formed of islets. These islets variable in shape, size and distribution in all lobes of the pancreas as that of the (Guha \& Ghosh 1978 ) in birds. However, Smith (1974) in Japanese quail and Miakami and Ono (1962) in chicken mentioned that the islets localized mainly in the splenic lobe.

These islets were consisted of beta, alpha and delta cells, these results agree with Tarakcy et al., (2007) and Faris, (2012) in birds. On the other hand, stornelli et al., (2006) in ostrich and goose and Hamodi et al., (2013) in Guinea fowl and Common gull mentioned that delta cells were absent.

According to the population of the cells in the islets, the islets can be classified into beta islets, alpha islets and mixed islets these results were coincided with Das et al., (2003) in duck, Hamodi et al., (2013) in Guinea fowl. On the other side, Mobini (2013) mentioned that, the pancreatic islands consisted of different shapes of large alpha and small beta islets with the absence of mixed islet in pigeon. Moreover Hamodi et al., (2013) in Common gull said that, mixed islets are the only type of islets that present in the pancreas.

In our result, the beta islets contained a large number of beta cells with few alpha and delta cells. The alpha islets may contain only alpha cells or a large number of alpha cells with few numbers of beta cells (in the center of the islets) and delta cells. In contrast Motta et al., (1997), Saadatfar et al., (2014) in avian species, and Mobini (2013) in pigeon mentioned that, the beta islets were consisted of beta and delta cells whereas, alpha islets containing alpha and beta cells.
Beta cells are large ovoid or polygonal with a large nuclei with electron dense secretory granules about (180-300 nm) in size with the presence of halo zoon between limited membrane and the content. The cell organelles such as mitochondria, endoplasmic reticulum and free ribosomes were also present. This result contrast with those of Mikami and Mutoh, (1971) in chicken as they stated that there were three major types of polymorphic granules; spine or needle-shaped, sphere-shaped, and ringshaped; they are surrounded by a smooth membrane. Laurent, et al., (1988) in ducks, said that, the beta cells were ovoid or polygonal in shape and the cytoplasmic granules showed different shapes and size, which may be rounded in shape and surrounded by clear haloes between the limitative membrane and their contents or rode shape and other secretory granules were showed pleomorphism. Azza (2009) in rats mentioned that, the middle of the secretory granules was electron dense and enclosed by, electron lucent halo, also the mitochondria are scattered in the cytoplasm as fine rounded or plump filamentous, having dense matrix.

Alpha cells are elongated or polygonal and contain a large vesicular nucleus. Its cytoplasm contains spherical or oval electron dense secretory granules with ill distinct space between the limited membrane and the content and its size rang about $(450-550 \mathrm{~nm})$. Also the cell has a little amount of organelles. These results agree with Machino et al., (1966) in chicken and Laurent, et al., (1988) in ducks. But Mikami and Mutoh, (1971) in Chicken demonstrated a large, spherical or columnar alpha cells, which have lessdeveloped organelles and distinctive alpha granules. There was a single smooth membrane surrounded these dense, spherical granules and the matrix exhibited a glomerular appearance with high magnification.

Delta cells appear oval or triangular having a vesicular nucleus with electron 
dense chromatin, mitochondria, endoplasmic reticulum and free ribosomes are found. The cells contained spherical electron dense granules (300$450 \mathrm{~nm}$ ) in size. The limited membrane of the secretory granules of the cell closely adheres to the content. These conclusions were in agreement with Machino et al., (1966) in domestic fowl who mentioned that, delta granules, measuring mostly $350-550 \mathrm{~nm}$ in diameter. Also, Laurent, et al., (1988) said that, delta granules, measuring mostly 300-500 nm diameter in ducks. Mikami and Mutoh (1971) in chicken noticed, less electron dense rounded granules (diameter about $500 \mathrm{~nm}$ ), which partially enclosed by the unclear membrane in the delta cells.

The acid phosphatase has a lysosomal activity so it has the ability to digest the foreign bodies and with antagonism of the bacteria, therefore, it had an autolytic action (Seham 2004). Frank and Christensen (1968) mentioned that, auto-oxidation of the unsaturated fat in the droplets or in the membranous organelles of the cell resulting from the lysosomal activity of the acid phosphatase enzyme, but Vacca (1985) denoted that, the acid phosphatase catalyzes the hydrolysis of esters of orthophosphoric acid with various alcohols and phenols at low $\mathrm{pH}$. In our study the acid phosphatase activity showed strong to moderate reaction in the pancreatic islets also in the sporadic alpha and beta cells which found in between the acini, while the acinar cells showed relatively faint reaction. Hellerström (1963) detected marked reactions for acid phosphatases in the alpha (dark) islets and infrequent marginal beta (light) islet cells and an intense reaction was clearly restricted to cells located along the dark islet capillaries in ducks. These results disagree with Orci et al., (1971) who demonstrated that, only some Golgi cisternae and the secretory granules of $\beta$ cells were positive to acid phosphatase in adult rats.

The oxidative phosphorylation is one function of ATPase enzyme which is a specific type of alkaline phosphatase and it has an important role in the hydrolytic ability of ATP (Pearse 1977). In the current research, there were intense to a strong reaction in the pancreatic islets, as well as the sporadically distributed alpha and beta cells but the acinar cells showed weak reaction to ATPase. These results contradict with Hellerström (1963) who said that the light islet cells exhibited a pronounced reaction to ATPase, while the reaction was restricted in the dark islets to the capillary walls of ducks. In the exocrine pancreas, a positive reaction to ATPase was discovered in the capillaries and larger blood vessels. Also Kordás et al., (2004) in rats, detected a positive reaction to the ATPase in the pancreatic acini and its duct but it was not detectable in guinea pigs and humans.

Seham (2004) said that, the free glucose is released in the circulation due to hydrolysis of glucose esters by the action of alkaline phosphatase. Moreover, the alkaline phosphatase act as intermediaries in the metabolism of proteins, carbohydrates and lipids. Vacca (1985) established that, the energy released by hydrolysis of phosphate esters by the action of the alkaline phosphatase. In our result, the alkaline phosphatase activity was strong in the pancreatic islets and the acinar cells, meanwhile there was intense reaction in the wall of the blood vessels. Hellerström (1963) in ducks demonstrated an intense reaction to the alkaline phosphatase in the light islet cells but it occasionally in the dark islets often in close contact to the capillaries, exhibited a weak reaction. $\mathrm{He}$ added that acinar cells in addition to its ducts and the blood vessels were negative to the alkaline phosphatase activity. Jacoby (1946) found that, there was complete absence of the alkaline 
phosphatase in the pancreas of cattle, sheep, cat and man but the smallest ducts in the dog pancreas were strongly positive.

The SD considered as a mitochondrial enzyme, by increasing the metabolic activity of the cell the activity of the SD increased (Hoyda 2004). Moreover, the SD is concerned with ion pumping in order to reinstate quickly the polarization of the membrane after discharge Hussein (1988). So, in this work the activity of SD was strong in the pancreatic islets and the acinar cells. Hellerström (1963) in duck, there were intense reaction to succinic dehydrogenase in the acinar cells and the epithelial lining of the excretory duct. The reaction was less noticeable in the light islet cells, and still weaker in the dark islets, the reaction is restricted to cells neighboring the capillary walls. However, Lenzen and Panten (1983) mentioned that, the activities of SD in the pancreatic islets of rat and mouse were lesser than in the pancreatic acini. This means that, there was less number of mitochondria in pancreatic islet.

In conclusion, the current study provided a window on the histological, histochemical and ultrastructure of the ostrich pancreas however, future studies should be done to examine ostrich pancreas in more details.

\section{Acknowledgements:}

Eternal thanks to Prof. Dr. Hussein Edaroos; Department of Cytology and Histology, Faculty of Veterinary Medicine, Suez Canal University, Egypt and Prof. Dr. Alam Nafady; Department of Pathology, Faculty of Veterinary Medicine, Assiut University, Egypt for help in sample collection and cooperation. Dr. Heba M.A. Abdelrazek; Department of Physiology, Faculty of Veterinary Medicine, Suez Canal University, Ismailia, Egypt for revision.

\section{Conflict of interests}

The authors declare that they have no conflict of interests.

\section{REFERENCES}

Al-Sharoot HA (2016). Anatomical, Histological and Histochemical Architecture of pancreases in Early Hatched Goose (Anser anser). Kufa Journal For Veterinary Medical Sciences. 7: 147-153.

Aughey E, Frye FL (2001). Comparative veterinary histology with clinical correlates. CRC Press.

Azza A (2009). Attia: Histological and electron microscopic studies of the effect of B-Carotene on the pancreas of streptozotocin induced diabetic rats. Pakistan journal of biological Sciences. 12: 301-314.

Bacha AB, Gargouri Y, Bezzine S et al. (2007). Ostrich pancreatic phospholipase A2: Purification and biochemical characterization. Journal of Chromatography B. 857: 108-114.

Beheiry RR, Abdel-Raheem WA-A, Balah AM et al. (2018). Morphological, histological and ultrastructural studies on the exocrine pancreas of goose. BeniSuef University Journal of Basic and Applied Sciences.

Bozzola JJ, Russell LD (1999). Electron microscopy: principles and techniques for biologists. Jones \& Bartlett Learning.

Brand Z, Brand T, Brown C (2003). The effect of dietary energy and protein levels on production in breeding female ostriches. British Poultry Science. 44: 598-606.

Carleton HM, Drury RAB, Wallington EA (1980). Carleton's histological technique. Oxford University Press, USA.

Christaki E (2001). Some principles of ostriches nutrition and their products. Journal of the Hellenic Veterinary Medical Society. 52: 18-22.

Cook HC, Stirling R (1994). Manual of histological techniques and their 
diagnostic application. Churchill Livingstone.

Cooper K, Kennedy S, McConnell S et al. (1997). An immunohistochemical study of the distribution of biotin in tissues of pigs and chickens. Research in veterinary science. 63: 219-225.

Das A, Das R, Parida S et al. (2003). Histomorphological study on pancreas of duck (Anas boscas). Indian Journal of Animal Sciences (India).

Denbow DM (2015) Gastrointestinal anatomy and physiology. In: Sturkie's Avian Physiology (Sixth Edition). Elsevier. pp. 337-366.

Deprem T, TAŞÇI SK, BİNGÖL SA et al. (2015). Histological and histochemical studies on the structure of pancreatic Histological and histochemical studies on the structure of pancreatic ducts of the goose (Anser anser). Turkish Journal of Veterinary and Animal Sciences. 39: 62-68.

Egerbacher M, Böck P (1997). Morphology of the pancreatic duct system in mammals. Microscopy research and technique. 37: 407417.

Faris SA (2012). Anatomical and Histological study of the Pancreas of Pigeon. Journal of College of Education for Pure Science. 2: 6472.

Frandson RD, Wilke WL, Fails AD (2009). Anatomy and physiology of farm animals. John Wiley \& Sons.

Frank AL, Christensen AK (1968). Localization of acid phosphatase in lipofuscin granules and possible autophagic vacuoles in interstitial cells of the guinea pig testis. The Journal of cell biology. 36: 1-13.

Gatesy SM (1995). Handbook of Avian Anatomy: Nomina Anatomica Avium. Oxford University Press.
Ghosh S (2007). Effect of lithium chloride on the endocrine pancreas of domestic pigeon (Columba livia). Asian J Exp Sci. 21: 323326.

Guha B, Ghosh A (1978). A cytomorphological study of the endocrine pancreas of some Indian birds. General and comparative endocrinology. 34: 38-44.

Gulmez N (2003). Are glands present in goose pancreatic ducts? A light microscope study. J Pancreas. 4: 125-128.

Hamodi HM, Abed AA, Taha AM (2013). Comparative Anatomical, Histological and Histochemical Study of the Liver in Three Species of Birds. Rafidain journal of science. 24: 12-23.

Hellerström C (1963). Enzyme histochemistry of the pancreatic islets in the duck with special reference to the two types of $\mathrm{A}$ cells. Zeitschrift für Zellforschung und Mikroskopische Anatomie. 60: 688-710.

Hermes JC (1996). Raising ratites: Ostriches, emu, and rheas.

Hoyda ASK (2004). Histopathological and histochemical studies on the effect of the non-steroidal antiinflammatiry drug "celebrex" on the liver and kidney of albino rat. . In: Zoology. Suez Canal University.

Hussein H (1988). Comparative histological and histochemical studies on the abomasum of some ruminant animals [Egypt].

Jacoby F (1946). The pancreas and alkaline phosphatase. Nature. 158: 268.

Kadhim KK, Zuki A, Noordin $\mathrm{M}$ et al. (2010). Morphological study of pancreatic duct in red jungle fowl. African Journal of Biotechnology. 9: 7209-7215.

Kalliecharan R, Steeves J (1982). Light and electron microscopic 
immunohistochemical localization of somatostatin in the endocrine and exocrine portions of the pancreas of the chick embryo (Gallus domesticus). The Anatomical Record. 202: 349-357.

Kordás KS, Sperlágh B, Tihanyi T et al. (2004). ATP and ATPase secretion by exocrine pancreas in rat, guinea pig, and human. Pancreas. 29: 5360.

$\mathrm{Ku} \mathrm{S}-\mathrm{K}$, Lee J-H, Lee H-S (2000). An immunohistochemical study of the insulin-, glucagon-and somatostatin-immunoreactive cells in the developing pancreas of the chicken embryo. Tissue and Cell. 32: 58-65.

Laurent F, Hindelang C, Strosser MT et al. (1988). The ultrastructure of A, $\mathrm{B}$ and $\mathrm{D}$ pancreatic cells in normal and in diabetic ducks. Biological structures and morphogenesis. 1: 34-42.

Lenzen S, Panten U (1983). Characterization of succinate dehydrogenase and $\alpha$ glycerophosphate dehydrogenase in pancreatic islets. Biochemical medicine. 30: 349-356.

Lucini C, Castaldo L, Lai O (1996). An immunohistochemical study of the endocrine pancreas of ducks. European journal of histochemistry: EJH. 40: 45-52.

Machino $M$, SAKUMA $H$, ONOE $T$ (1966). The fine structure of the Dcells of the pancreatic islets in the domestic fowl and their morphological evidence of secretion. Archivum histologicum japonicum. 27: 407-418.

Mescher A (2010). Junqueira's: Basic histology. Mescher AL (ed.). 12th. Mc Graw Hill Companies, Singapore.

Mihail N, Crăcium C (1982). An ultrastructural description of the cell types in the endocrine pancreas of the pigeon. Anatomischer Anzeiger. 152: 229-237.

Mikami S-i, Mutoh K (1971). Light-and electron-microscopic studies of the pancreatic islet cells in the chicken under normal and experimental conditions. Zeitschrift für Zellforschung und Mikroskopische Anatomie. 116: 205-227.

Mikami S-I, Ono K (1962). Glucagon deficiency induced by extirpation of alpha islets of the fowl pancreas. Endocrinology. 71: 464-473.

Mobini B (2013). Histochemical and histological studies on the pancreas in mature pigeon (Columba Livia). Eur J Exp Biol. 3: 148-152.

Mobini B, Aghaabedi B (2009). Histological and histochemical studies on pancreas of native turkey in Iran. Veterinary Journal.

Motta PM, Macchiarelli G, Nottola SA et al. (1997). Histology of the exocrine pancreas. Microscopy research and technique. 37: 384398.

Mutoh K-i, Wakuri H, Taniguchi K (1999). Intercalated duct cells in the chicken pancreatic islet with special reference to the alloxan administration. Journal of veterinary medical science. 61: 493-496.

Nagasao J, Sugiyama D, Yoshioka K et al. (2003). Morphological relationship between intercalated duct and pancreatic islet in streptozotocin and/or camostat mesilate administrations in the chicken. Anatomia, histologia, embryologia. 32: 89-93.

Orci L, Stauffacher W, Rufener C et al. (1971). Acid phosphatase activity in secretory granules of pancreatic beta cells of normal rats. Diabetes. 20: 385-388.

Pearse A (1977). Histochemistry, Theoretical and Applied (3r d Ed. Vol. I) Churchill. London. 
Pieler T, Chen Y (2006). Forgotten and novel aspects in pancreas development. Biology of the Cell. 98: 79-88.

Saadatfar Z, Asadian M, Alishahi E (2014). Structure of pancreas in Palam Dove (Streptoplia selegalensis). Iranian Journal of Veterinary Science and Technology. 3: 25-32.

Saber A, Emara S, AboSaeda O (2009). Light, Scanning and Transmission Electron Micro-scopical Study on the Oviduct of the Ostrich (Struthio camelus). J Vet Anat. 2: 79-89.

Seham A (2004). Histological and histochemical studies on the gastrointestinal mucosa of the ostrich (Struthio camelus). PH. D., Fac. of Vet. Med., Suze Canal Univ.

Simsek N, Alabay B (2008). Light and electron microscopic examinations of the pancreas in quails (Coturnix coturnix japonica). Revue de Medecine Veterinaire. 159: 198206.

Smith PH (1974). Pancreatic islets of the Coturnix quail. A light and electron microscopic study with special reference to the islet organ of the splenic lobe. The Anatomical Record. 178: 567-585.

Stornelli MR, Ricciardi MP, Miragliotta V et al. (2006). Morpho-structural study of the pancreas and pancreatic duct in ostrich (Struthio camelus L.). Acta Veterinaria Brno. 75: 157-160.

Take G, Ilgaz C, Erdogan D et al. (2007). A comparative study of the ultrastructure of submandibular, parotid and exocrine pancreas in diabetes and fasting. Saudi medical journal. 28: 28-35.

Tarakci B, Yaman M, Bayrakdar A et al. (2007). Immunohistochemical detection of GonadotropinReleasing Hormone (GnRH) in porcupine (Hystrix cristata) pancreas. Revue de médecine vétérinaire. 158: 134.

Vacca L (1985). Calcification. Laboratory Manual of Histochemistry Raven Press, New York, NY, USA. 334-336. 


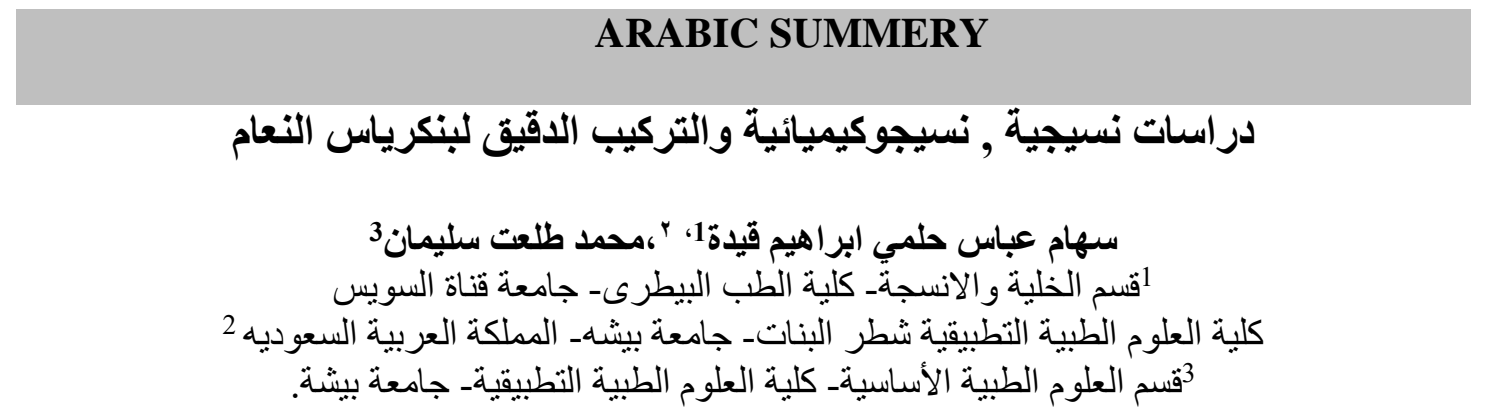

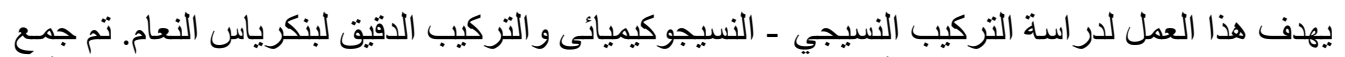

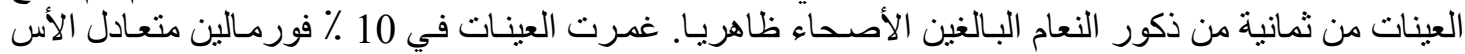

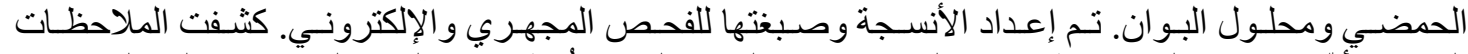

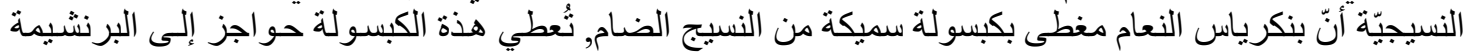

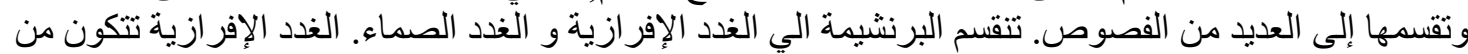

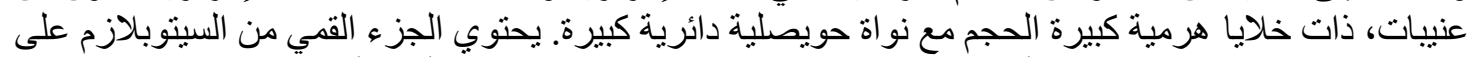

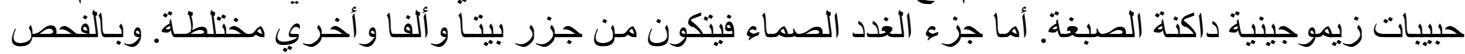

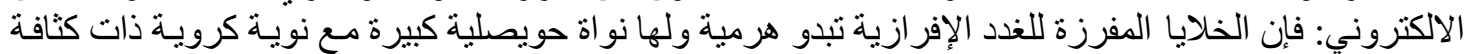

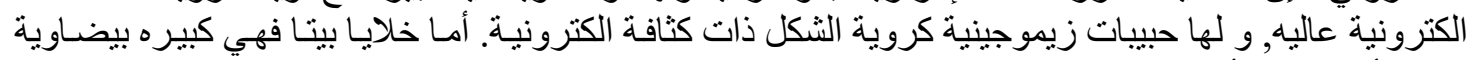

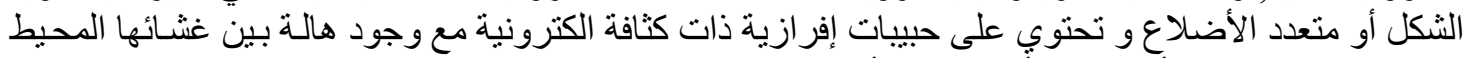

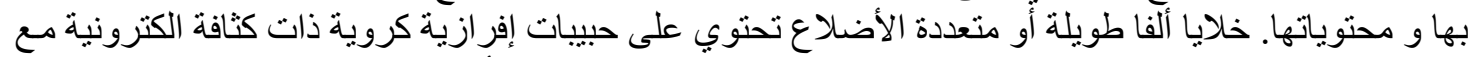

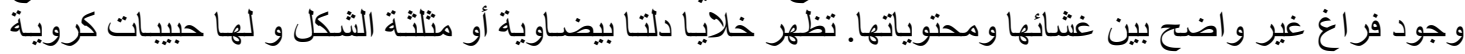

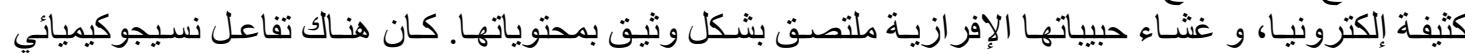
متفاوت مع الفوسفاتيز الحمضى , الفوسفاتيز القاعدى , الأدينوزين تر ائي فوسفاتيز و السكسينيك ديهايدروجينيز نائيز في الخلايا الافرازية وفي الجزر البنكرياسية. 